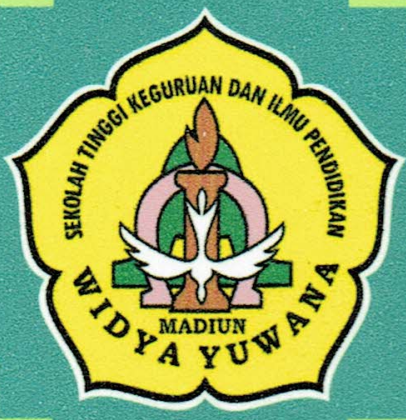

Vol, 7, Tahun ke.4, April 2012

ISSN; 2085-0743

REMAJA: SUMBER DAYA INSANI MENYONGSONG KEMANDIRIAN BANGSA INDONESIA JS. Wibowo Singgih

REMAJA DAN PENGHAYATAN EKARISTI: SUATU HABITUS

BARU

Ola Rongan Wilhelmus

REMAJA KATOLIK, GEREJA, DAN EKARISTI Agustinus Supriyadi

PERAYAAN EKARISTI HARI MINGGU DI PAROKI DAN PERKEMBANGAN HIDUP ROHANI KAUM REMAJA: SEBUAH PELUANG Don Bosco Karnan Ardijanto

STRATEGI MENJADIKAN REMAJA MUSIM SEMI BAGI MASYARAKAT, BANGSA DAN GEREJA Antonius Tse

PROBLEM DAN ABORSI DITINJAU DARI MORAL KATOLIK SERTA USAHA MEMAKNAI LITURGI UNTUK MENGURANGI

PRAKTEK ABORSI DI TENGAH REMAJA KATOLIK Antonius Virdei Eresto Gaudiawan

PROBLEM REMAJA DAN PENILAIAN MORAL KATOLIK TENTANG SEX DI LUAR NIKAH Suparto

DOSA DAN RAHMAT SEKRAMEN PENGAKUAN DOSA BAGI REMAJA Robertus Joko Sulistyo

ANIMASI PERAYAAN TOBAT YANG TEPAT BAGI REMAJA Aloysius Suhardi

REMAJA DAN MASA DEPANNYA: SEBUAH UPAYA PASTORAL BAGI REMAJA Albert I Ketut Deni Wijaya

BELAJAR SEBAGAI AKTIVITAS REMAJA MEMPERSIAPKAN MASA DEPAN Agustinus Wisnu Dewantara

Lembaga Penelitian

Sekolah Tinggi Keguruan dan Ilmu Pendidikan "Widya Yuwana" MADIUN 


\section{JPAK}

Vol. 7, Tahun ke-4, April 2012

ISSN; 2085-0743

\section{DAFTAR ISI}

03 Editorial

05 REMAJA: SUMBER DAYA INSANI MENYONGSONG KEMANDIRIANQBANGSAINDONESIA JS Wibowo Singgih

14 REMAJA DAN PENGHAYATAN EKARISTI: SUATU HABITUS BARU Ola Rongan Wilhelmus

26 REMAJA KATOLIK, GEREJADAN EKARISTI Agustinus Supriyadi

43 PERAYAAN EKARISTI HARI MINGGU DI PAROKI DAN PERKEMBANGAN HIDUP ROHANI KAUM REMAJA: SEBUAH PELUANG

Don Bosco KarnanArdijanto

58 STRATEGI MENJADIKAN REMAJA MUSIM SEMI BAGI MASYARAKAT, BANGSADAN GEREJA Antonius Tse

75 PROBLEM REMAJA DAN ABORSI DITINJAU DARI SEGI MORAL KATOLIK SERTA USAHA MEMAKNAI LITURGI UNTUK MENGURANGI PRAKTEK ABORSI DI TENGAHN REMAJAKATOLIK Antonius Virdei Eresto Gaudiawan

102 PROBLEM REMAJA DAN PENILAIAN MORAL KATOLIK TENTANG SEX DI LUAR NIKAH Suparto

119 DOSA DAN RAHMAT SAKRAMEN PENGAKUAN DOSA BAGI REMAJA Robertus Joko Sulistyo 


\section{ANIMASI PERAYAAN TOBAT YANG TEPAT BAGI}

REMAJA

Aloysius Suhardi

142 REMAJA DAN MASA DEPANNYA: SEBUAH UPAYA PASTORALBAGI REMAJA Albert I Ketut Deni Wijaya

155 BELAJAR SEBAGAI AKTIVITAS REMAJA MEMPERSIAPKAN MASA DEPAN

Agustinus Wisnu Dewantara 


\title{
DOSA DAN RAHMAT SAKRAMEN PENGAKUAN DOSA BAGI REMAJA
}

\author{
Robertus Joko Sulistyo \\ Sekolah Tinggi Keguruan dan Ilmu Pendidikan Agama Katolik \\ (STKIP) Widya Yuwana Madiun
}

\begin{abstract}
Abstrak
Rahmat sakramen tobat berdayaguna untuk memulihkan kembali hidup remaja dan membuatnya menjadi anak Allah lagi setelah jatuh dalam dosa. Namun minimnya pemahaman remaja tentang hakikat sakramen tobat, kekayaan rahmat yang terkandung di dalamnya, maupun tata cara penerimaannya menyebabkan remaja enggan untuk menerima sakramen tobat. Di sini Gereja, terutama para petugas pastoral dipanggil untuk memberikan gambaran yang terang tentang kekayaan rahmat Allah dalam sakramen tobat sehingga remaja sadar dan giat untuk menimba rahmat Allah yang melimpah dalam sakramen tobat.
\end{abstract}

Key Words : Remaja, Dosa, Rahmat, Sakramen Pengakuan Dosa.

\section{Pendahuluan}

Terdapat fenomena bahwa kamar pengakuan dosa jarang dikunjungi. Umat, khususnya remaja, hanya mengaku dosa jikalau menjelang Natal dan Paskah, atau mengaku dosa apabila Gereja mengagendakan pengakuan dosa. Sekelompok remaja pernah mengemukakan pendapat mereka bahwa pengakuan dosa hanya merupakan suatu kewajiban saja. Mereka juga mengatakan: "Malu, kalau harus mengakukan dosa-dosa". Karena jikalau ada sedikit saja halangan seperti hujan gerimis, maka sudah cukup dijadikan alasan untuk tidak datang ke tempat pengakuan dosa. Apakah yang menjadi penyebabnya? Bisa dikatakan bahwa penyebabnya ialah para remaja kurang mengerti bahwa sakramen tobat atau mengakukan dosa itu dapat membawa pembaharuan hidup dalam diri seseorang dan 
membuatnya menjadi anak Allah lagi setelah jatuh dalam dosa.

Melalui tulisan ini penulis hendak menunjukkan bahwa mengaku dosa itu merupakan anugerah kasih Allah yang membuat seseorang kembali menjadi anak Allah. Bagian pertama tulisan ini menguraikan pemahaman dasar tentang apa itu Sakramen Tobat; bagian kedua, mendiskusikan sakramen tobat dalam semangat Konsili Vatikan II; dan bagian terakhir membicarakan bagaimana melakukan pengakuan dosa secara baik

\section{Apa itu Dosa?}

Dosa digambarkan dalam Alkitab sebagai pelanggaran hukum Allah (bdk. 1 Yoh 3:4) dan pemberontakan melawan Allah (bdk. U1 9:7; Yos 1:18). Dosa berawal dari Lucifer, "si bintang timur, putra fajar," yang paling cantik dan gagah perkasa dari semua malaikat. Karena tidak puas dengan semua kekuasaan dan kemewahan yang ada padanya, dia ingin menjadi Allah yang mahatinggi. Hal ini menyebabkan ia jatuh dalam dosa, dan terjadinya awal dosa (bdk. Yes 14:12-15). Setelah jatuh ke dalam dosa, Lucifer berubah nama menjadi Iblis. Iblis inilah yang membawa dosa kepada manusia di taman Eden. Iblis mencobai Adam dan Hawa dengan godaan yang sama: "engkau akan menjadi sama seperti Allah."

Kejadian 3 menjelaskan pemberontakan Adam dan Hawa melawan Allah dan perintah-perintahNya. Dosa Adam dan Hawa ini diwariskan kepada setiap generasi umat manusia sebagai keturunan Adam. Dalam Surat Paulus kepada jemaat di Roma 5;12 dikatakan bahwa melalui Adam dosa masuk ke dalam dunia dan kematian diwariskan kepada semua orang karena "upah dosa adalah maut" (Rm 6:23).

Karena Adam, kecenderungan untuk berbuat dosa masuk ke dalam diri setiap manusia dan membuat kodrat manusia menjadi berdosa. Ketika jatuh ke dalam dosa, kodrat Adam diubah menjadi dosa dan berontak melawan Allah dan kehendak-Nya. Perlawanan terhadap Allah ini mengakibatkan seseorang mengalami kematian secara rohani. Dosa dan akibatnya ini diwariskan pula kepada semua orang sebagai keturunan Adam. Dosa yang diwariskan dari Adam mengakibatkan setiap manusia menjadi orang-orang berdosa bukan karena melakukan kesalahan malainkan karena mewariskan kodrat Adam yang telah berdosa. Situasi ini disebut sebagai dosa warisan. Sama seperti setiap orang mewarisi karakteristik fisik dari 
orangtuanya, demikian juga setiap orang secara alami mewarisi kodrat dosaAdam. Raja Daud meratapi kodrat manusia yang berdosa ini dalam Mzm 51:7: "Sesungguhnya, dalam kesalahan aku diperanakkan, dalam dosa aku dikandung ibuku."

Menurut St. Agustinus, dosa adalah perbuatan atau perkataan atau keinginan yang bertentangan dengan hukum abadi. Hukum abadi sendiri merupakan Budi Ilahi atau kehendak Tuhan yang harus dipelihara, ditaati dan tidak dilanggar. Pelanggaran terhadap kehendak Ilahi menghantar manusia kepada penderitaan dan kebinasaan hidup. St. Tomas Aquino menambahkan bahwa ciri kedosaan dari perbuatan manusia terletak dalam kurangnya kesesuaian antara sikap dan perbuatan manusia dengan Budi Ilahi. Dengan kata lain dosa adalah perbuatan buruk manusia ( $b d k$. Piet Go, 2003, hal. 32-33) karena bertentangan dengan kehendak Allah. Dengan melakukan dosa, manusia menjauhkan diri dari Allah sebagai sumber kasih, kebaikan dan keselamatan. Oleh karena itu dosa juga diartikan sebagai avertio a Deo et convertio ad creaturas, penjauhan diri manusia dari Tuhan dan kelekatan pada ciptaan (bdk. Piet Go, 2003, hal.33).

Dosa memiliki beberapa dimensi, yakni dimensi teologal Kristologis, sosial-eklesial dan personal-transpersonal. Pertama, dimensi teologal Kristologis. Dengan istilah teologal Kristologis dimaksudkan pribadi sasaran yang juga terkena oleh dosa yang dilakukan manusia dan sekaligus juga segi adikodrati dosa dalam sejarah keselamatan yang memuncak pada Kristus (Piet Go, 2003, hal.35). Dimensi ini mencakup dosa melawan Tuhan dan dosa karena kelekatan pada ciptaan. Dosa pada dimensi ini juga mengandung arti tidak menghargai karya keselamatan Allah melalui Kristus.

Kedua, dimensi sosial-eklesial. Dimaksud dengan dimensi sosial ialah pandangan tentang dosa yang tidak diisolir melainkan dipandang melampaui segi privat dan individual. Dimensi sosial dalam arti langsung mengenai sesama. Sedangkan dimensi eklesial adalah segi khusus dimensi sosial sejauh mengenai Gereja sebagai umat Allah.

Dimensi personal-transpersonal. Dimaksud dengan dimensi personal-transpersonal ialah dosa dalam diri manusia memiliki dua arah, yakni arah (keluar) dari diri manusia dan arah (masuk) dari diri manusia. Dosa ke luar dari diri manusia mengandung arti bahwa dosa itu tidak lain dari perbuatan seorang pribadi mausia atau actus humanus. "Akulah yang telah berbuat". Dosa karena yang menjadi 
subjek dari perbuatan dosa itu ialah aku sendiri dan karena itu aku tidak bisa mengelakkan tanggung jawab atas dosa itu. Sedangkan dosa ke arah person ialah dosa karena perbuatan egosentris (demi dan untuk diri sendiri) serta penolakan terhadap panggilan Ilahi untuk keluar dari diri sendiri, memperbaiki serta menyempurnakan diri sendiri.

\section{Sakramen Tobat dalam Semangat Konsili Vatikan II}

Dosa menghasilkan jurang pemisah antara manusia dengan Allah. Manusia yang berdosa semakin jauh dari Allah dan tidak bisa mengalami belas kasih dan kebaikan Allah. Sakramen tobat dilakukan untuk menghapus dosa dan memperdamaikan manusia dengan Allah dan sekaligus membuat manusia kembali menjadi anak-anakAllah.

"Mereka yang menerima sakramen tobat memperoleh pengampunan dari belas kasihan Allah atas penghinaan mereka terhadap-Nya, sekaligus mereka didamaikan dengan Gereja, yang telah mereka lukai dengan berdosa, dan yang membantu pertobatan mereka dengan cinta kasih, teladan, serta doa-doanya." (LG 11)

LG 11 ini mau menjelaskan bahwa dosa membuat manusia terpisah dari Allah dan Gereja. Karena dosa dan akibatnya ini maka manusia memerlukan Sakramen Tobat. Sakramen ini memiliki dimensi eklesial dan berfungsi mendamaikan kembali manusia dengan Allah sehingga manusia dapat mengalami kembali hidup damai dengan Allah. Di sini Allah sendiri yang mengambil inisiatif menawarkan pendamaian ini Yesus Kristus Putra-Nya sebagai pendamaian manusia. Berkat wafat dan kebangkitan Kristus, manusia diperdamaikan kembali Allah. Itulah sebabnya dalam rumusan absolusi dinyatakan : "Allah Bapa yang berbelas kasih telah mendamaikan dunia dengan diri-Nya melalui wafat dan kebangkitan Putra-Nya." Dengan kata lain, sakramen tobat menghadirkan misteri wafat dan kebangkitan Kristus sebagai peristiwa yang mendamaikan manusia denganAllah. Santo Paulus dalam suratnya kepada jemaat di Roma menulis:

"Karena waktu kita masih lemah, Kristus telah mati untuk kita orang-orang durhaka pada waktu yang ditentukan oleh Allah.... Akan tetapi Allah menunjukkan kasih-Nya kepada kita, oleh karena Kristus telah mati untuk kita, ketika kita masih berdosa. Lebih-lebih, karena kita sekarang telah 
dibenarkan oleh darah-Nya, kita pasti akan diselamatkan dari murka Allah. Sebab jikalau kita, ketika masih seteru, diperdamaikan dengan Allah oleh kematian Anak-Nya, lebihlebih kita, yang sekarang telah diperdamaikan, pasti akan diselamatkan oleh hidup-Nya!" (Rm 5:6; 8-10).

Sebenarnya melalui pembaptisan, manusia menanggapi tawaran pendamaian Allah ini melalui imannya kepada Allah dan pertobatan (E. Martasudjita, 2003:324). Akan tetapi dalam perjalanan waktu sebagai manusia yang telah dibaptis, manusia masih tetap mudah jatuh dalam dosa. Dosa tersebut membuat hubungan dengan Allah menjadi renggang, dan bahkan putus (dimensi teologal Kristologis). Melalui undangan Tuhan untuk pertobatan dan sakramen tobat, hubungan dengan Allah dipulihkan kembali. Manusia yang telah dibaptis dan jatuh dalam dosa dipilihkan dan diangkat lagi menjadi anak-anak Allah.

Sakramen tobat mendamaikan kembali hubungan manusia dengan Allah dan Gereja. Dosa yang memutuskan hubungan manusia dengan Gereja dipulihkan kembali melalui rahmat Allah yang diperoleh lewat sakramen tobat. Dalam hubungan antara dosa dan Gereja, Paulus menggambarkan Gereja sebagai satu tubuh, dan karena itu apabila salah satu bagian dari tubuh itu terluka maka luka itu akan dirasakan juga oleh seluruh tubuh (bdk. 1Kor 12:12-31). Demikian pula apabila salah satu anggota Gereja berdosa maka akibat dari dosa itu akan dirasahkan pula oleh seluruh anggota Gereja sebagai satu tubuh.

Sakramen tobat juga mendamaikan hubungan manusia dengan semua makhluk dan lingkungan di mana manusia berada. Perbuatan dosa yang dilakukan manusia membuat relasinya dengan semua makhluk dan lingkungan rusak. Sebagai contoh, membuang sampah di sembarangan tempat membuat lingkungan rusak dan sesama terganggu serta ketularan penyakit. Disini manusia memerlukan sakramen tobat sebab sakramen tobat dapat membuat manusia sadar atas perbuatan dosa dan akibat-akibat sosial dari dosa. Sakramen tobat juga membuat seseorang meninggalkna dosadosanya. Misalnya orang tidak lagi membuang sampah di sembarangan tempat dan merasa terdorong ikutserta menciptakan lingkungan hidup yang bersih dan bebas penyakit.

Sakramen tobat ini selain memberikan pendamaian relasi dengan Tuhan, Gereja, diri sendiri, sesama, dan lingkungan juga menganugerahkan Roh Kudus sebagai pengampunan dan pembaruan hidup. "Seluruh hasil pengakuan ialah bahwa ia memberi kembali rahmat Allah dan menyatukan kita dengan Dia dalam persahabatan 
erat“(Katekismus Gereja Katolik, art. 1468).

\section{Bagaimana Mengaku Dosa yang Baik?}

Pengakuan dosa selalu mulai dengan mengingat. Caranya, pikirkan orang-orang yang ada di sekitar anda, diawali dengan pikiran tentang keluarga, kemudian yang lainnya seperti sanak saudara, tetangga, rekan sekerja, teman sekolah, orang yang anda potong jalannya di jalan raya minggu lalu, dan sebagainya.

Pikirkan tentang kejadian-kejadian baru ini dalam hidup yang melibatkan orang-orang tersebut. Pengaruh apakah yang anda berikan kepada mereka? Apakah ada sesuatu yang anda lakukan sehingga menyakiti mereka? Apakah sebetulnya ada sesuatu yang bisa anda lakukan, tetapi anda menolak untuk lakukannya? Adakah seseorang yang membutuhkan pertolongan dan anda tidak memberikan pertolongan? Pertanyaan-pertanyaan ini diajukan kepada diri anda sendiri sebelum anda melakukan pengakuan dosa. Pertanyaan-pertanyaan ini bisa dilakukan pada waktu ibadat tobat dan sebelum pengakuan dosa secara pribadi di kamar pengakuan.

Tata cara pelaksanaan Sakramen Pengakuan dapat berbedabeda, tetapi biasanya imam akan memulainya dengan membukan percakapan sejenak atau memulai dengan sebuah doa. Terkadang imam membacakan suatu perikop dari Kitab Suci tentang belas kasih Tuhan. Umat beriman tidak perlu khawatir tentang rumusanrumusan atau doa-doa tertentu. Memang mungkin ada suatu rumusan standart pengakuan yang dipakai, tetapi pada prinsipnya proses pengakuan dosa harus berjalan lancar dan praktis. Umat beriman yang melakukan pengakuan dosa harus merasa santai dan dengan jelas mengatakan kepada imam sudah berapa lama sejak pengakuan yang terakhir tidak melakukan pengakuan dosa, kemudian berusaha menjawab dengan jelas pertanyaan-pertanyaan yang mungkin diajukan imam selama pengkuan.

Hal yang terpenting dalam pengakuan dosa ialah meminta pertolongan. Jika anda terbiasa tanpa pikir panjang mengucapkan suatu daftar panjang tentang dosa-dosa yang telah dilakukan, maka mungkin lebih baik anda mencoba berkonsentrasi pada beberapa dosa diantaranya dan kemudian meminta arahan dari imam untuk bertobat. Bisa saja imam akan meminta keterangan lebih lanjut tetang dosa yang anda lakukan, tetapi hal itu dilakukan imam dengan tujuan semata-mata untuk memberikan nasehat yang terbaik untuk anda. Hal utama yang perlu anda diingat adalah bahwa pengakuan itu bersifat 
pribadi dan hanya dimaksudkan untuk menolong. Anda berada di sana untuk didamaikan kembali dengan Allah.

Bila anda melakukan pengakuan secara baik maka anda akan keluar dari kamar pengakuan dengan perasaan lega! Anda harus melaksanakan penitensi penyembuhan sesegera mungkin. Anda yang telah mendapat pengampunan Allah dan dengan demikian hubungan anda dengan Allah, Gereja dan sesama dipulihkan. Salah satu hal terindah tentang pengampunan dosa adalah bahwa Tuhan mengampuni dan melupakan dosa anda! Begitu dosa-dosa anda telah diampuni, anda diperbaharui dalam rahmat Tuhan. Anda harus mempunyai niat yang kuat untuk menghindari dosa di masa mendatang.

\section{Penutup}

Dosa yang dilakukan mengakibatkan hubungan dengan Tuhan, sesama, diri sendiri dan ubahkan dengan lingkungan retak dan bahkan putus. Tuhan menawarkan kasih pengampunan melalui Gereja dan Sakramen Tobat. Jadi, malu atau enggan mengaku dosa tidak dibenarkan. Sebab dengan menerima sakramen tobat umat beriman disembuhkan, diampuni dan dipulihkan kembali menjadi anak-anak Allah. Hidup umat beriman diperbarui dalam Roh Kudus, sehingga hidupnya semakin menyerupai hidup Kristus (bdk. Rm 8 : 29).

\section{Daftar Pustaka}

Apa definisi dosa?, http://www.gotguestions.org/indonesia/definisidosa.html, diakses tanggal 11 Oktober 2011.

Embuiru, Herman P (terj)., 1998. Katekismus Gereja Katolik. Ende: Arnoldus

Go, Piet., 2003. Teologi Moral Fundamental. Malang:(Diktat) STFT Widya Sasana (Diktat)

Hardawiryana, R (terj)., 1993. Dokumen Konsili Vatikan II. Jakarta : Obor

Martasudjita, E., 2003. Sakramen-Sakramen Gereja: Tinjauan Teologis, Liturgis, dan Pastoral. Yogyakarta: Kanisius

LBI., 2000. Alkitab Katolik Deuterokanonika: Dengan Pengantar dan Catatan Lengkap. Ende: Arnoldus

Lonsdale, Richard., Sakramen Pengampunan Dosa, http://www.standreas.or.id/content/view/366/1/, diakses tanggal 11 Oktober 2011. 


\section{PERSYARATAN PENULISAN ILMIAH DI JURNAL JPAK WIDYA YUWANA MADIUN}

01. Jumal IImiah JPAK Widya Yuwana memuat hasil-hasil Penelitian, Hasil Refleksi, atau Hasil Kajian Kritis tentang Pendidikan Agama Katolik yang belum pernah dimuat atau dipublikasikan di Majalah/Jurnal IImiah lainnya.

02. Artikel ditulis dalam Bahasa Indonesia atau Inggris sepanjang 7500-10.000 kata dilengkapi dengan Ábstrak sepanjang 50-70 kata dan 3-5 kata kunci.

03. Artikel Hasil Refleksi atau Kajian Kritis memuat: Judul Tulisan, Nama Penulis, Instansi tempat bernaung Penulis, Abstrak (Indonesia/Inggris), Kata-kata Kunci, Pendahuluan (tanpa anak judul), Isi (subjudul-subjudul sesuai kebutuhan), Penutup (kesimpulan dan saran), Daftar Pustaka.

04. Artikel Hasil Penelitian memuat: Judul Penelitian, Nama Penulis, Instansi tempat bernaung Penulis, Abstrak (Indonesia/lnggris), Kata-kata Kunci, Latar Belakang Penelitian, Tinjauan Pustaka, Metode Penelitian, Hasil Penelitian, Penutup (kesimpulan dan saran), Daftar Pustaka

05. Catatan-catatan berupa referensi disajikan dalam model catatan lambung.

Contoh: Menurut Caputo, makna religius kehidupan harus berpangkal pada pergulatan diri yang terus menerus dengan ketidakpastian yang radikal yang disuguhkan oleh masa depan absolut (Caputo, 2001: 15)

06. Kutipan lebih dari empat baris diketik dengan spasi tunggal dan diberi baris baru.

Contoh: Religions claim that they know man an the world as these really are, yet they they differ in their views of reality. Question therefore arises as to how the claims to truth by various religions are related. Are they complementary? Do they contradict or overlap one another? What -according to the religious traditions themselves-is the nature of religious knowledge? (Vroom, 1989: 13)

07. Kutipan kurang dari empat baris ditulis sebagai sambungan kalimat dan dimasukkan dalam teks dengan memakai tanda petik.

Contoh: Dalam kedalaman mistiknya, Agustinus pernah mengatakan "saya tidak tahu apakah yang saya percayai itu adalah Tuhan atau bukan." (Agustinus, 1997: 195)

08. Daftar Pustaka diurutkan secara alfabetis dan hanya memuat literature yang dirujuk dalam artikel. Contoh;

Tylor, E. B., 1903. Primitive Culture: Researches Into the Development of Mythology,

Philosophy, Religion, Language, Ert, and Custom, John Murray: London

Aswinarno, Hardi, 2008. "Theology of Liberation As a Constitute of Consciousness," dalam Jurnal RELIGIONo. I, April 2008, hal. 25-35.

Borgelt, C., 2003. Finding Association Rules with the Apriori Algorthm, http:/hwww.fuzzi.cs.uni-magdeburg.de/-borgelt/aprioril. Juni 20, 2007

Derivaties Research Unicorporated. http//fbox.vt.edu.10021/business/finance/ dmc/RU/content.html.Accesed May 13, 2003 